\title{
触 New Disease Reports \\ Amazon lily: a new natural host of Tomato spotted wilt virus
}

\author{
M.A.V. Alexandre ${ }^{1 *}$, L.M.L. Duarte ${ }^{1}$, R. Harakava ${ }^{2}$, A.L.R. Chaves $^{1}$, J.M. Marque ${ }^{3}$ and E.W.Kitajima ${ }^{4}$ \\ ${ }^{1}$ Laboratório de Fitovirologia Fisiopatológica, Instituto Biológico, São Paulo, SP, Brazil; ${ }^{2}$ Laboratório de Bioquímica \\ Fitopatológica, Instituto Biológico, São Paulo, SP, Brazil; ${ }^{3}$ Laboratório Atena, Atibaia, SP, Brazil; ${ }^{4}$ Departamento de \\ Fitopatologia e Nematologia, Escola Superior de Agricultura Luiz de Queiróz, USP, Piracicaba, SP, Brazil
}

*E-mail: alexand@biologico.sp.gov.br

Received: 25 Jun 2014. Published: 13 Sep 2014. Keywords: Tospovirus, ornamental, Eucharis grandiflora, flower bulb

The Amazon lily (Eucharis grandiflora, Amaryllidaceae) is found in tropical rain forests and has been widely cultivated as an ornamental plant. Although viral infections do not usually kill these plants, Amazon lily mosaic virus, Hippeastrum mosaic virus, Nerine latent virus, Cucumber mosaic virus, Impatiens necrotic spot virus (INSV) and a member of the Anulavirus genus, tentatively designated as Amazon lily mild mottle virus, have been reported in Amazon lilies (Alexandre et al., 2011; Fuji et al., 2013). In the case of INSV, it is worth noting that the virus was originally identified in this host was described as the impatiens strain of TSWV (TSWV-I). This was subsequently reclassified as INSV and recognised by ICTV (International Committee on Taxonomy) as a distinct species (Murphy et al., 1995). Chlorotic rings and spots were observed on $E$. grandiflora plants from a commercial nursery in Atibaia county, São Paulo State, Brazil (Fig. 1). Disease symptom incidence was estimated at 60\%. In order to identify the causal agent, transmission tests, electron microscopy (EM), RT-PCR and sequencing were carried out.

Symptoms were induced following mechanical inoculation on Petunia hybrida, Chenopodium amaranticolor and Datura stramonium. Up to four months after inoculation, Eucharis and Hippeastrum remained symptomless and the virus could not be recovered from these hosts. EM observations of negatively stained leaf extract from naturally infected $E$. grandiflora revealed the presence of a large number of quasispherical particles, approximately $100 \mathrm{~nm}$ in diameter. EM of thin sections of the leaf lesions also identified enveloped particles in the lumen of the endoplasmic reticulum (Fig. 2). Total RNA from E. grandiflorum and D. stramonium (inoculated host plants) was separately extracted and an approximately 450 bp fragment, corresponding to the non-translated region and partial nucleocapsid protein, was amplified by RT-PCR, using the pair of primers BR60 and BR65 (Eiras et al., 2001). The amplicon was sequenced and the sequence deposited in GenBank (Accession No. KC894720). Analysis indicated that this sequence shared the highest identity (96.5\%) with isolates of Tomato spotted wilt virus (TSWV). Further analysis was conducted by construction of rooted trees (PAUP software) with different TSWV isolate nucleotide sequences from multiple regions of the world, including Brazil, and different hosts. These revealed that the Eucharis TSWV sequence (KC894720) shared a common ancestor with the Brazilian and Italian isolates (Fig. 3) but the TSWV isolates could not be separated by geographical origin and host. This is the first report of Amazon lily as a natural host to TSWV.

\section{References}

Alexandre MAV, Duarte LML, Rivas EB, Cilli A, Harakava R, Galleti SR, Kitajima EW, 2011. Hippeastrum mosaic virus diagnosed in Hippeastrum and Eucharis in Brazil. Journal of Plant Pathology 93, 643-649.

Eiras M, Resende RO, Missiaggia AA, De Ávila AC, 2001. RT-PCR and dot blot hybridization for a universal detection of tospoviruses.

Fitopatologia Brasileira 26, 170-175. http://dx.doi.org/10.1590/S0100-41582001000200009

Fuji S, Kikuchi M, Ueda S, Toda T, Furuya H, Fukumoto F, Hanada K, 2013. Characterization of a new anulavirus isolated from Amazon lily plants. Archives of Virology 158, 201-206.

http://dx.doi.org/10.1007/s00705-012-1467-8

Murphy FA, Fauquet CM, Bishop DHL, Ghabrial SA, Jarvis AW, Martelli GP, Mayo MA, Summers MD, eds. 1995. Virus taxonomy: classification and nomenclature of viruses. Sixth Report of International Committee on Taxonomy of Viruses. (Archives of Virology Supplement). NY, USA: Springer Verlag.

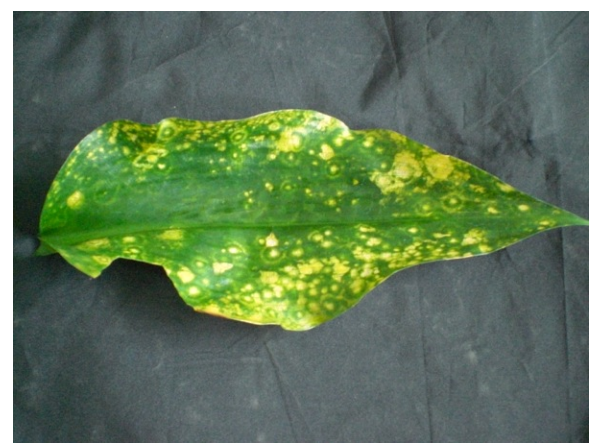

Figure 1

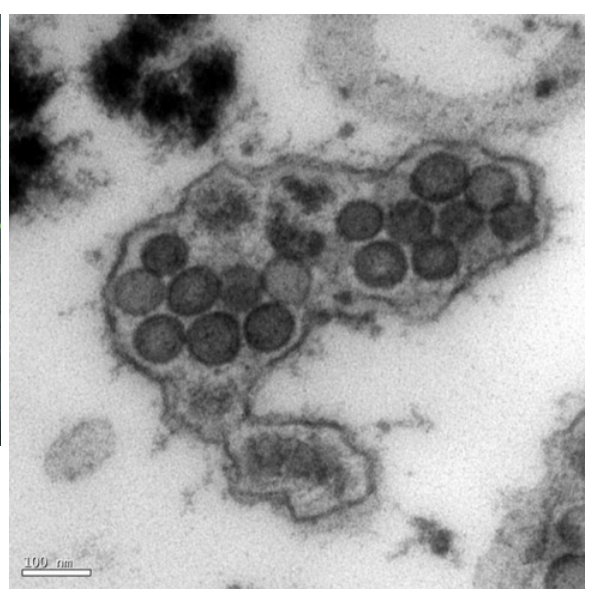

Figure 2

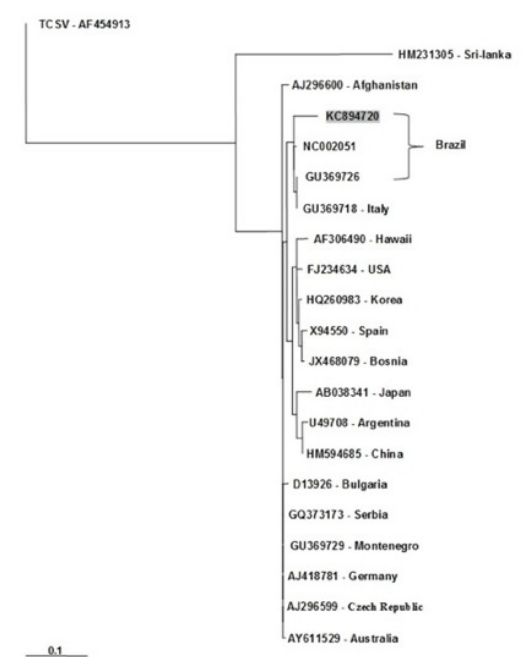

Figure 3

To cite this report: Alexandre MAV, Duarte LML, Harakava R, Chaves ALR, Marque JM, E.W.Kitajima, 2014. Amazon lily: a new natural host of Tomato spotted wilt virus. New Disease Reports 30, 13. http://dx.doi.org/10.5197/j.2044-0588.2014.030.013 